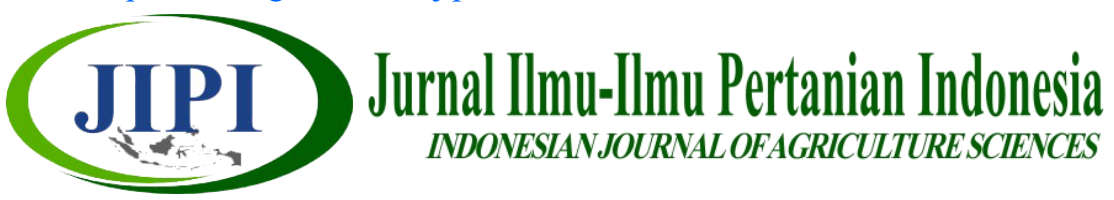

\title{
PENGARUH PEMBERIAN PUPUK HAYATI MIKORIZA DAN PUPUK KANDANG AYAM TERHADAP PERTUMBUHAN DAN HASIL TANAMAN KACANG PANJANG (Vigna sinensis L.) DI ULTISOL
}

\author{
Eisal Vepin Nainggolan ${ }^{1}$, Yudhi Harini Bertham ${ }^{2 *}$, Sigit Sudjatmiko ${ }^{1}$ \\ ${ }^{1}$ Program Studi Agroekoteknologi, Fakultas Pertanian Universitas Bengkulu \\ ${ }^{2}$ Program Studi Ilmu Tanah, Fakultas Pertanian Universitas Bengkulu \\ * Corresponding Author:yudhyhb@unib.ac.id
}

\begin{abstract}
[EFFECT OF MYCORRHIZAL BIOFERTILIZER AND CHICKEN MANURE ON GROWTH AND YIELD OF COWPEA (Vigna sinensis L.) IN ULTISOL]. This study aims to 1) obtain the interaction of mycorrhizal biofertilizers and chicken manure on cowpea in ultisol and 2) determine the best dose of mycorrhizal biofertilizers for the growth and yield of cowpea plants, also find the best dose of chicken manure on the growth and yield of string beans. The study was conducted in April 2019 at the experimental garden, Integrated Zone of the Faculty of Agriculture, UNIB, Kelurahan Kandang Limun, Muara Bangkahulu District, Bengkulu City. This study used a factorial Randomized Completely Block Design (RCBD) with two factors and three replications. The first factor is the administration of a dose of mycorrhizal biofertilizer, i.e., 0 (without mycorrhizae), $2.5 \mathrm{~g} / \mathrm{plant}, 5 \mathrm{~g} / \mathrm{plant}$, and 7.5 $\mathrm{g} / \mathrm{plant}$. The second factor is the provision of chicken manure doses of 5 tons $/ \mathrm{ha}, 10$ tons $/ \mathrm{ha}$, and 15 tons $/ \mathrm{ha}$. Each experimental unit consisted of 25 plants with some sample plots of 5 plants. There is an interaction between mycorrhizal fertilizer $5 \mathrm{~g} /$ plant with chicken manure 5 tons/ha, which gives the best results on variable weight pod pods equal to $1.55 \mathrm{~kg} / \mathrm{m}^{2}$ and pod weight of $15.46 \mathrm{~kg} / \mathrm{ha}$. The application of mycorrhizal biological fertilizer at a dose of $5 \mathrm{~g} / \mathrm{plant}$ has good vegetative growth compared to other mycorrhizal doses. It shows the highest results based on the average number of flowers/plants and the number of pods/plants. Doses of chicken manure up to a dose of 15 tons/ha do not significantly increase growth and yield of cowpea.
\end{abstract}

Keyword: cowpea, ultisol, micorrhizal, chicken manure

\begin{abstract}
ABSTRAK
Penelitian ini bertujuan untuk mendapatkan interaksi pupuk hayati mikoriza dan pupuk kandang ayam terhadap tanaman kacang panjang di ultisol serta menentukan dosis pupuk hayati mikoriza yang terbaik terhadap pertumbuhan dan hasil tanaman kacang panjang. dan dosis pupuk kandang ayam yang terbaik terhadap pertumbuhan dan hasil tanaman kacang panjang. Penelitian dilaksanakan pada bulan April 2019 bertempat di kebun percobaan, Zona Terpadu Fakultas Pertanian UNIB, Kelurahan Kandang Limun, Kecamatan Muara Bangkahulu, Kota Bengkulu. Penelitian ini menggunakan Rancangan Acak Kelompok Lengkap (RAKL) faktorial dengan dua faktor dan tiga ulangan. Faktor pertama adalah pemberian dosis pupuk hayati mikoriza yaitu, 0 (tanpa mikoriza), 2,5 g/tanaman, $5 \mathrm{~g} /$ tanaman dan 7,5 g/tanaman. Faktor kedua adalah pemberian dosis pupuk kandang ayam yaitu 5 ton/ha, 10 ton/ha, dan 15 ton/ha. Setiap satuan percobaan terdiri dari 25 tanaman dengan jumlah sampel perpetakan yaitu 5 tanaman. Terdapat interaksi antara pupuk mikoriza $5 \mathrm{~g} /$ tanaman dengan pupuk kandang ayam 5 ton/ha yang memberikan hasil terbaik pada variabel bobot polong perpetak yaitu sebesar $1,55 \mathrm{~kg} / \mathrm{m}^{2}$ dan bobot polong sebesar $15,46 \mathrm{~kg} / \mathrm{ha}$. Pemberian pupuk hayati mikoriza dosis $5 \mathrm{~g} /$ tanaman memiliki pertumbuhan vegetatif yang baik dibandingkan dengan dosis mikoriza lainnya dan menunjukkan hasil yang tertinggi berdasarkan rata-rata jumlah bunga/tanaman dan jumlah polong/tanaman. Dosis pupuk kandang ayam hingga dosis 15 ton/ha tidak meningkatkan secara nyata pertumbuhan dan hsil kacang panjang.
\end{abstract}

Kata kunci: Ultisol, pupuk hayati mikoriza, pupuk kandang ayam, tanaman kacang panjang 


\section{PENDAHULUAN}

Kacang panjang (Vigna sinensis. L) salah satu jenis tanaman leguminosae, yang berbentuk perdu, pertumbuhan tanaman ini bersifat merambat $\mathrm{k}$ eatas dengan cara melilit. Komoditi ini banyak dimanfaatkan oleh masyarakat Indonesia sebagai bahan untuk dikonsumsi dalam bentuk segar maupun diolah menjadi sayuran (Rahayu, 2007). Kandungan zat gizi yang terdapat dalam kacang panjang cukup lengkap yaitu mengandung $50 \mathrm{kkal}$, Protein 3,40 g, Lemak 0,40 g, Karbohidrat 8,50 mg, Kalsium $106 \mathrm{mg}$, Fosfor $63 \mathrm{mg}$, Besi 1,40 mh, Vitamin A295 mg (Cahyono, 2003).

Berdasarkan data statistik, hasil produksi kacang panjang Indonesia selama lima tahun terakhir cenderung mengalami penurunan dari tahun ke tahun. Berikut data produksi tanaman kacang panjang pada tahun 2013 sampai dengan tahun 2017 berturut-turut yaitu 450.859 ton/tahun, 450.727 ton/tahun, 395.524 ton/tahun, 388.071 ton/tahun dan 381.185 ton/tahun. (Badan Pusat Statistik, 2018).

Penurunan produksi tanaman kacang panjang disebabkan oleh sistem budidaya tanaman kacang panjang yang belum tepat atau belum maksimal dengan tanaman itu sendiri, serta penyebaran tanah ultisol dan penggunaan pupuk anorganik secara berlebihan sehingga membuat rendahnya produktivitas kacang panjang di Bengkulu. Kondisi tanah yang kurang memadai akan unsur hara akibat kurangnya bahan organik pada tanah dan penggunaan lahan secara terus menerus, sehingga kesuburan tanah menjadi rendah dan kurang mendukung untuk pertumbuhan tanaman.

Tanah ultisol memiliki potensi yang besar untuk dijadikan sebagai pilihan strategis pengembangan pertanian ke depannya untuk mengimbangi penyempitan lahan subur (Subowo, 2012). ultisol merupakan salah satu jenis tanah yang sebaran luasnya di Indonesia mencapai $29,7 \%$ atau sekitar 51 juta ha (Tambunan et al., 2014). Menurut data BPTP Bengkulu (2014) bahwa 41,22\% jenis tanah di daerah Bengkulu adalah jenis tanah ultisol. Tanah ultisol merupakan tanah yang memiliki tingkat kesuburan rendah dengan $\mathrm{pH}$ berkisar 4,2-4,3 serta memiliki kandungan unsur hara, kapasitas tukar kation (KTK) dan kejenuhan basah (KB) yang rendah. Sentana (2010) menjelaskan bahwa pengunaan pupuk organik adalah solusi permasalahan lingkungan pertanian yang berpeluang tinggi di masa depan. Penerapan pupuk anorganik yang terus menerus dinilai menurunkan produktivitas lahan pertanian (Suparta et al., 2012; Manuhuttu et al., 2014).

Mikoriza merupakan cendawan yang mampu masuk ke dalam akar tanaman untuk membantu memenuhi ketersediaan unsur hara bagi tanaman. Beberapa peranan dari cendawan mikoriza sendiri di antaranya adalah membantu akar dalam meningkatkan serapan fosfor (P) dan unsur hara lainnya seperti $\mathrm{N}, \mathrm{K}, \mathrm{Zn}, \mathrm{Co}, \mathrm{S}$ dan Mo dari dalam tanah, meningkatkan ketahanan tanaman terhadap kekeringan, memperbaiki agregat tanah. Salah satu alternatif untuk mengatasi kekurangan unsur hara terutama memfasilitasi ketersediaan fosfat adalah dengan menggunakan mikoriza (Nurmala, 2014).

Selain pemberian mikoriza, perlu juga pemberian pupuk kandang ayam yang di aplikasikan untuk menambah bahan organik pada tanah untuk menjaga kesuburan tanah dan untuk mencukupi unsur hara mikro dan makro bagi tanaman. Pupuk kandang yang diaplikasikan adalah kotoran ayam, pupuk kandang ayam merupakan hasil pemanfaatan kotoran ayam diolah menjadi suatu bahan organik yang dapat digunakan tanaman untuk mencukupi kebutuhan unsur hara. Keunggulan dari pupuk kandang ayam sendiri yaitu memiliki kandungan hara yang cukup tinggi yakni 2,6\% (N), $2,9 \%(\mathrm{P})$, dan $3,4 \%(\mathrm{~K})$ dengan perbandingan $\mathrm{C} / \mathrm{N}$ ratio 8,3 (Sutedjo, 2002).

Untuk itu perlu dilakukan upaya untuk meningkatkan kembali produktivitas kacang panjang dengan sistem budidaya organik dengan pemberian pupuk hayati mikoriza dan pupuk kandang dengan dosis tertentu diharapkan mampu meningkatkan ketersediaan unsur hara/ bahan organik tanah serta memperbaiki struktur tanah.

Penelitian ini bertujuan untuk mendapatkan interaksi pupuk hayati mikoriza dan pupuk kandang ayam terhadap tanaman kacang panjang di ultisol, menentukan dosis pupuk hayati mikoriza yang terbaik terhadap pertumbuhan dan hasil tanaman kacang panjang. Serta menentukan dosis pupuk kandang ayam yang terbaik terhadap pertumbuhan dan hasil tanaman kacang panjang.

\section{METODE PENELITIAN}

Penelitian dilaksanakan pada bulan April 2019 sampai dengan Juli 2019 bertempat di kebun percobaan Zona Terpadu Fakultas Pertanian UNIB, Kelurahan Kandang Limun, Kecamatan Muara Bangkahulu, Kota Bengkulu.

Penelitian menggunakan Rancangan Acak Kelompok Lengkap (RAKL) faktorial, dengan dua faktor perlakuan dan tiga ulangan. Faktor Pertama adalah pemberian pupuk hayati Mikoriza yang terdiri atas 4 taraf dosis perlakuan yakni : (Tanpa Mikoriza) $0 \mathrm{~g}$ /tanaman, Mikoriza 2,5 g/tanaman, Mikoriza $5 \mathrm{~g} /$ tanaman Mikoriza $7,5 \mathrm{~g} /$ tanaman. Faktor kedua adalah pemberian pupuk kandang ayam yang terdiri atas 3 taraf dosis perlakuan yakni pupuk kandang 5 ton/ha, pupuk kandang 10 ton/ha, dan pupuk kandang 15 ton/ha.

Variabel pengamatan yang diamati adalah jumlah daun (helai), diameter batang ( $\mathrm{mm}$ ), jumlah bunga/ tanaman, jumlah polong, panjang polong/tanaman $(\mathrm{cm})$, bobot polong/petak $\left(\mathrm{kg} / \mathrm{m}^{2}\right)$, bobot polong total $(\mathrm{kg} / \mathrm{ha})$, bobot kering tanaman $(\mathrm{g})$, dan bobot kering akar (g).

Data yang diperoleh dianalisis menggunakan Analisis Varian(ANAVA) taraf5\%. Data yang menunjukkan 
pengaruh nyata dibandingkan dengan menggunakan Duncan Multiple Range Test (DMRT) pada taraf 5\%.

\section{HASIL DAN PEMBAHASAN}

Hasil analisis data menunjukkan bahwa terdapat interaksi nyata $\mathrm{P} \leq 0,05$ ) pada peubah bobot polong/ petak dan bobot polong total. Pengaruh mandiri dosis pupuk hayati mikoriza nyata terhadap semua peubah pertumbuhan dan hasil kecuali bobot kering akar. Sedangkan pengaruh mandiri pupuk kandang ayam tidak nyata $(P>0,05)$ pada semua peubah pertumbuhan hasil hasil tanaman kacang panjang.

Bobot polong/petak tanaman kacang panjang menunjukkan hasil berbeda tidak nyata pada perlakuan tanpa mikoriza (kontrol) yang dikombinasikan dengan berbagai taraf dosis pupuk kandang ayam. Namun pada perlakuan mikoriza dosis 2,5 g/tanaman yang dikombinasi dengan perlakuan pupuk kandang ayam dosis 10 ton/ha memberikan hasil tertinggi yaitu 1,65 $\mathrm{kg} / \mathrm{m}^{2}$ yang berbeda nyata dengan pemberian dosis pupuk kandang ayam 5 ton/ha dan 15 ton/ha. Pada bobot polong/petak yang diberi perlakuan mikoriza dosis 5 $\mathrm{g} /$ tanaman yang dikombinasikan dengan pupuk kandang dosis 10 ton/ha memberikan hasil tertinggi yaitu 1,83 $\mathrm{kg} / \mathrm{m}^{2}$ yang berbeda nyata pada perlakuan dosis pupuk kandang ayam 5 ton/ha dan 15 ton/ha. Dosis pupuk hayati mikoriza 7,5 g/tanaman yang dikombinasikan dengan berbagai taraf dosis pupuk kandang ayam menunjukkan hasil bobot polong/petak yang berbeda tidak nyata (Tabel 1).

Tabel 1. Pengaruh dosis pupuk hayati mikoriza dan pupuk kandang ayam terhadap bobot polong/petak $\left(\mathrm{kg} / \mathrm{m}^{2}\right)$

\begin{tabular}{c|c|c|c}
\hline Dosis pupuk hayati & \multicolumn{3}{c}{ Dosis pupuk kandang (ton/ha) } \\
\cline { 2 - 4 } mikoriza $(\mathrm{g} / \mathrm{tan})$ & 5 & 10 & 15 \\
\hline \multirow{2}{*}{0} & $1,23 \mathrm{~b}$ & $1,24 \mathrm{a}$ & $1,26 \mathrm{a}$ \\
& $\mathrm{A}$ & $\mathrm{A}$ & $\mathrm{A}$ \\
\hline \multirow{2}{*}{2,5} & $1,41 \mathrm{ab}$ & $1,65 \mathrm{a}$ & $1,50 \mathrm{a}$ \\
\hline \multirow{2}{*}{5} & $\mathrm{~B}$ & $\mathrm{~A}$ & $\mathrm{~B}$ \\
\hline \multirow{2}{*}{7,5} & $1,55 \mathrm{ab}$ & $1,83 \mathrm{a}$ & $1,63 \mathrm{a}$ \\
\hline & $\mathrm{B}$ & $\mathrm{A}$ & $\mathrm{B}$ \\
\hline & $1,62 \mathrm{a}$ & $1,62 \mathrm{a}$ & $1,83 \mathrm{a}$ \\
\hline
\end{tabular}

Keterangan : Angka-angka yang diikuti oleh huruf kapital yang sama pada baris yang sama berbeda tidak nyata pada DMRT 5\%. Angka-angka yang diikuti oleh huruf kecil yang sama pada kolom yang sama berbeda tidak nyata pada DMRT $5 \%$

Hal ini dikarenakan pada pemberian kombinasi pupuk hayati mikoriza dosis $5 \mathrm{~g} /$ tanaman dan pupuk kandang ayam 5 ton/ha, pupuk yang diberikan sudah mampu membantu akar tanaman dan dapat menyediakan unsur hara yang dapat diserap dan diperlukan tanaman kacang panjang. Mikoriza mempunyai kemampuan dalam menguraikan $\mathrm{P}$ yang terikat dalam tanah agar dapat diserap akar tanaman. Hifa yang mengeluarkan enzim fosfatase sehingga $\mathrm{P}$ di dalam tanah akan terlarut dan tersedia bagi tanaman sehingga merangsang pertumbuhan dan pembentukan buah pada tanaman kacang panjang. Tanaman yang terinfeksi mikoriza mampu menyerap unsur $\mathrm{P}$ yang lebih tinggi dibandingkan tanaman yang tidak terinfeksi (Musfal, 2010). Penelitian Hartanti (2013) menunjukkan bahwa dengan pemberian mikoriza dengan dosis $5 \mathrm{~g}$ mampu meningkatkan diameter batang, panjang tongkol dan persentase akar terinfeksi mikoriza. Pemberian bahan organik 5 ton/ha menghasilkan jumlah polong kacang panjang/petak paling banyak sebanyak 54,58 buah/petak sedangkan perlakuan tanpa bahan organik menghasilkan jumlah polong/petak paling sedikit sebanyak 38,53 buah. Jumlah polong yang dihasilkan akan berdampak pada bobot polong/petak (Andi et al, 2012).

Bobot polong tanaman kacang panjang menunjukkan hasil berbeda tidak nyata pada perlakuan tanpa mikoriza (kontrol) yang dikombinasi dengan berbagai taraf dosis pupuk kandang ayam. Pada bobot polong yang diberi mikoriza dosis $2,5 \mathrm{~g} /$ tanaman dan dikom -binasikan dengan pupuk kandang ayam pada dosis 10 ton/ha menunjukkan hasil tertinggi dan berbeda nyata terhadap pupuk kandang ayam dosis 5 ton/ha dan 15 ton/ha. Perlakuan mikoriza dosis $5 \mathrm{~g} / \operatorname{tanaman}$ yang dikombinasikan dengan pupuk kandang ayam dosis 10 ton/ha menunjukkan rata-rata bobot polong tertinggi yaitu $18,320 \mathrm{~kg} / \mathrm{ha}$ dan berbeda nyata pada dosis pupuk kandang 5 ton/ha dan 15 ton/ha. Sedangkan bobot polong yang diberi perlakuan mikoriza dosis 7,5 g/tanaman yang dikombinasi dengan pupuk kandang ayam pada berbagai taraf dosis perlakuan menunjukkan berbeda tidak nyata. Kombinasi perlakuan yang menghasilkan bobot polong tanaman kacang panjang terbaik yaitu pada perlakuan pemberian mikoriza dosis $5 \mathrm{~g} /$ tanaman dan pupuk kandang ayam dosis 5 ton/ha dengan bobot polong 15,46 ton/ha (Tabel 2).

Tabel 2. Pengaruh pupuk hayati mikoriza dan pupuk kandang ayam terhadap bobot polong $(\mathrm{kg} / \mathrm{ha})$

\begin{tabular}{|c|c|c|c|}
\hline Dosis pupuk hayati & \multicolumn{3}{|c|}{ Dosis pupuk kandang (ton/ha) } \\
\cline { 2 - 4 } mikoriza $(\mathrm{g} / \tan )$ & 5 & 10 & 15 \\
\hline 0 & $12,30833 \mathrm{c}$ & $12,38833 \mathrm{~b}$ & $12,64000 \mathrm{c}$ \\
\hline 0 & $\mathrm{~A}$ & $\mathrm{~A}$ & $\mathrm{~A}$ \\
\hline 2,5 & $14,06333 \mathrm{~b}$ & $16,51167 \mathrm{a}$ & $15,00500 \mathrm{~b}$ \\
\hline 5 & $\mathrm{~B}$ & $\mathrm{~A}$ & $\mathrm{~B}$ \\
\hline & $15,46667 \mathrm{a}$ & $18,32000 \mathrm{a}$ & $16,29833 \mathrm{~b}$ \\
\hline 7,5 & $\mathrm{~B}$ & $\mathrm{~A}$ & $\mathrm{~B}$ \\
\hline & $16,24667 \mathrm{a}$ & $16,20667 \mathrm{a}$ & $18,34667 \mathrm{a}$ \\
\hline & $\mathrm{A}$ & $\mathrm{A}$ & $\mathrm{A}$ \\
\hline
\end{tabular}

Keterangan : Angka-angka yang diikuti oleh huruf kapital yang sama pada baris yang sama berbeda tidak nyata pada DMRT 5\%. Angka-angka yang diikuti oleh huruf kecil yang sama pada kolom yang sama berbeda tidak nyata pada DMRT 5\%

Setiawan et al. (2012) menyatakan bobot polong/petak berkorelasi positif dengan bobot polong total berarti semakin besar bobot polong/petak secara 
otomatis bobot polong secara total akan semakin besar pula. Mikoriza dan bahan organik sudah mampu menyuplai kebutuhan hara tanaman kacang panjang di ultisol dengan memperhatikan dosis yang diberikan sehingga tidak mengganggu pertumbuhan tanaman.

Jumlah daun tanaman kacang panjang terbanyak yaitu diperoleh pada perlakuan pemberian pupuk hayati mikoriza dengan dosis $5 \mathrm{~g}$ tanaman yang menunjukkan berbeda nyata terhadap perlakuan pemberian mikoriza dosis 2,5 g/tanaman dan juga kontrol (tanpa mikoriza). Namun demikian jumlah daun yang dihasilkan ini berbeda tidak nyata terhadap perlakuan pemberian mikoriza dosis 7,5 g/tanaman (Tabel 3). Pemberian mikoriza dosis $5 \mathrm{~g} /$ tanaman di dalam tanah pada tanaman kacang panjang sudah bekerja maksimal dan sudah mampu membantu akar tanaman dalam menyuplai ketersediaan unsur N. Nitrogen berperan dalam merangsang pertumbuhan vegetatif tanaman terutama pada pembentukan daun yang juga dapat mempengaruhi tanaman untuk melakukan fotosintesis, sehingga apabila dosis yang diberi lebih dari $5 \mathrm{~g} /$ tanaman mengakibatkan mikoriza yang bekerja didalam tanah tidak bekerja secara efektif. Penentuan dosis yang tepat sangat diperlukan, karena unsur hara yang berlebihan akan mengganggu pertumbuhan dan perkembangan tanaman (Suryati \& Anom, 2014). Unsur hara yang paling berpengaruh terhadap pertumbuhan dan perkembangan daun adalah unsur N (Lakitan, 2004). Beberapa efek positif yang diperoleh tanaman inang akibat bersimbiosis dengan mikoriza, yaitu antara lain terjadinya peningkatan daya serap hara, terutama unsur hara $\mathrm{N}$ (Widiastuti, 2003).

Tabel 3. Pengaruh pupuk hayati mikoriza terhadap pertumbuhan tanaman kacang panjang

Pada umumnya semakin besar perkembangan

\begin{tabular}{c|c|c|}
\hline $\begin{array}{c}\text { Dosis Mikoriza } \\
(\mathrm{g} / \text { tanaman })\end{array}$ & $\begin{array}{c}\text { Jumlah daun } \\
\text { (helai) }\end{array}$ & $\begin{array}{c}\text { Diameter batang } \\
(\mathrm{mm})\end{array}$ \\
\hline 0 & $23,93 \mathrm{~b}$ & $6,18 \mathrm{c}$ \\
\hline 2,5 & $25,02 \mathrm{~b}$ & $6,65 \mathrm{~b}$ \\
\hline 5 & $26,93 \mathrm{a}$ & $6,87 \mathrm{ab}$ \\
\hline 7,5 & $26,77 \mathrm{a}$ & $7,07 \mathrm{a}$ \\
\hline
\end{tabular}

Keterangan : Angka-angka yang diikuti oleh huruf yang sama pada kolom yang sama berbeda tidak nyata pada DMRT $5 \%$

diameter batang, sehingga keadaan organ-organ pada bagian atasnya seperti jumlah daun akan semakin baik pula (Suryati \& Anom, 2014). Pertumbuhan tanaman kacang panjang menunjukkan data diameter yang paling besar adalah pada perlakuan pemberian mikoriza dosis 7,5 g/tanaman yaitu 7,07 mm yang menunjukkan berbeda tidak nyata pada perlakuan pemberian mikoriza dosis $5 \mathrm{~g} /$ tanaman, namun berbeda nyata terhadap perlakuan mikoriza dengan dosis 2,5 g/tanaman dan juga kontrol (tanpa mikoriza) (Tabel 3). Pemberian mikoriza memberikan efek positif, kemampuan mikoriza dalam membantu akar tanaman dalam menyerap unsur hara $\mathrm{N}$ sehingga pertumbuhan dan perkembangan batang tanaman berlangsung dengan baik. Hendri et al. (2015) menyatakan bahwa unsur hara $\mathrm{N}$ yang diperlukan oleh tanaman untuk pembentukan klorofil, dan merangsang pertumbuhan vegetatif tanaman seperti batang, cabang, dan daun. Semakin baik pertumbuhan vegetatif tanaman maka proses fotosintesis akan berjalan dengan baik sehingga fotosintat yang dihasilkan makin banyak (Zainal et al., 2014). Pemberian mikoriza dengan dosis $5 \mathrm{~g}$ sudah mampu meningkatkan diameter batang, panjang tongkol jagung dan persentase akar terinfeksi mikoriza (Hartanti, 2013). Pemberian mikoriza dosis 2,5 g/tanaman dan $5 \mathrm{~g} / \operatorname{tanaman}$ masih belum mampu mencapai ukuran maksimal dan masih berkembang sehingga pada pemberian dosis $7,5 \mathrm{~g} /$ tanaman didapat diameter batang terbesar yaitu $7,07 \mathrm{~mm}$.

Fungi mikoriza dapat meningkatkan serapan nitrogen (N) dan kalium (K) (Musfal, 2010). Pemberian mikoriza pada tanaman kacang-kacangan juga dapat meningkatkan serapan unsur mikro Cu dan $\mathrm{Zn}$ serta penyerapan air dan unsur hara yang cukup oleh tanaman menyebabkan pertumbuhan tanaman menjadi lebih baik (Sastrahidayat, 2011).

Jumlah bunga/tanaman pada tanaman kacang panjang jumlah bunga terbanyak terdapat pada pemberian mikoriza dosis $5 \mathrm{~g} /$ tanaman yaitu 32,75 bunga yang menunjukkan berbeda tidak nyata dengan pemberian mikoriza dengan dosis $7,5 \mathrm{~g} /$ tanaman dan $2,5 \mathrm{~g} /$ tanaman namun berbeda nyata terhadap kontrol (tanpa mikoriza) (Tabel 4). Mikoriza yang diberikan pada tanaman mampu membantu akar tanaman dalam menyediakan kebutuhan unsur hara yang diperlukan dalam merangsang pertumbuhan jumlah bunga kacang panjang. Pemberian mikoriza dosis $5 \mathrm{~g} /$ tanaman ke dalam tanah sudah mampu memenuhi unsur hara dalam memacu pertumbuhan hingga terbentuknya bunga atau munculnya bunga, sehingga pada pemberian mikoriza dosis 7,5 g/tanaman menunjukkan rata-rata jumlah bunga tidak meningkat lagi. Hasil penelitian pada tanaman tomat menunjukkan bahwa pemberian mikoriza dapat meningkatkan jumlah bunga tomat/tanaman rata-rata 16,5 kuntum dibandingkan dengan tanpa mikoriza yang hanya berjumlah14 kuntum (Gunadi \& Subhan, 2007).

Rata-rata jumlah terbanyak dihasilkan oleh pemberian mikoriza dosis $5 \mathrm{~g} /$ tanaman yaitu 22,04 polong yang berbeda tidak nyata dibandingkn pemberian mikoriza dosis 2,5 g/tanaman dan 7,5 g/tanaman namun berbeda nyata dibandingkan kontrol (tanpa mikoriza) (Tabel 4). Mikoriza di dalam tanah mampu bekerja maksimal dan mampu mengikat unsur hara $\mathrm{P}$ sehingga dapat diserap akar tanaman. Hifa yang mengeluarkan enzim fosfatase sehingga $\mathrm{P}$ di dalam tanah akan terlarut dan tersedia bagi tanaman dalam merangsang pertumbuhan dan pembentukan buah pada tanaman 
kacang panjang (Winarso, 2005). Fungsi penting fosfor dalam tanaman yaitu dalam proses fotosintesis, respirasi, transfer dan penyimpanan energi, pembelahan dan pembesaran sel serta proses-proses di dalam tanaman lainnya. Tanaman yang terinfeksi mikoriza mampu menyerap unsur $\mathrm{P}$ yang lebih tinggi dibandingkan tanaman yang tidak terinfeksi (Musfal, 2010).

Tabel 4. Pengaruh pupuk hayati mikoriza terhadap hasil tanaman kacang panjang

Panjang polong terpanjang yaitu $54,71 \mathrm{~cm}$

\begin{tabular}{|c|c|c|c|c|}
\hline Dosis Mikoriza & Jumlah bunga/ & Jumlah polong & Panjang polong/ & Bobot kering/ \\
\hline (g/tanaman) & tanaman & & $\operatorname{tanaman}(\mathrm{cm})$ & tanaman $(\mathrm{g})$ \\
\hline 0 & $31,6 \mathrm{~b}$ & $18,8 \mathrm{~b}$ & $51,94 \mathrm{~b}$ & $77,11 \mathrm{~b}$ \\
\hline 2,5 & $32,71 \mathrm{a}$ & $21,57 \mathrm{a}$ & $54,71 \mathrm{a}$ & $84,22 \mathrm{~b}$ \\
\hline 5 & $32,75 \mathrm{a}$ & $22,04 \mathrm{a}$ & $53,15 \mathrm{ab}$ & $85,55 \mathrm{~b}$ \\
\hline 7,5 & $32,73 \mathrm{a}$ & $21,82 \mathrm{a}$ & $52,92 \mathrm{~b}$ & 99,44 a \\
\hline
\end{tabular}

dihasilkan oleh pemberian mikoriza dosis $2,5 \mathrm{~g} /$ tanaman Hasil ini berbeda tidak nyata dibanddingkan pemberian mikoriza $5 \mathrm{~g} /$ tanaman, namun berbeda nyata dibandingkan perlakuan mikoriza dosis 7,5 g/tanaman dan kontrol (tanpa mikoriza) (Tabel 4). Pemberian mikoriza dosis 2,5g/ tanaman sudah mampu menyuplai ketersediaan unsur hara dalam jumlah yang cukup dan seimbang bagi pertumbuhan dan produksi tanaman. Mikoriza mampu menstimulus pembentukan hormon-hormon pertumbuhan tanaman, seperti hormon sitokinin dan auksin. Hormon sitokinin dan auksin membantu dalam pembelahan sel serta pemanjangan sel pada tanaman kacang panjang sehingga tanaman yang diberi mikoriza mempengaruhi terhadap pertumbuhan panjang polong kacang panjang.

Bobot kering tanaman kacang panjang terberat rata-rata 99,44 $\mathrm{g}$ dan bobot terendah yaitu $77,11 \mathrm{~g}$ (Tabel 4). Pemberian mikoriza dosis 7,5 g/tanaman menunjukkan hasil berbeda nyata dibandingkan pemberian mikoriza dengan dosis dosis 2,5 g/tanaman,5 $\mathrm{g} /$ tanaman dan kontrol (tanpa mikoriza). Bobot kering tanaman dapat digunakan sebagai indikator untuk menentukan berapa jumlah kadar air yang diserap tanaman serta status unsur hara dari suatu tanaman. Tanaman bermikoriza memiliki bobot kering yang lebih tinggi dibanding tanaman yang tidak bermikoriza (Permatasari \& Nurhidayati, 2014). Bobot kering tanaman merupakan petunjuk adanya kandungan protein dan organik lainnya yang merupakan hasil fotosintesis yang dapat diendapkan setelah kadar air dikeringkan. Semakin besar bobot kering tanaman menunjukkan semakin efisien proses fotosintesis yang terjadi dan produktivitas serta perkembangan sel jaringan semakin tinggi dan cepat (Lizawati et al., 2014).

Pemberian pupuk kandang ayam hingga dosis 15 ton/ha belum mampu meningkatkan pertumbuhan dan hasil kacang panjang secara nyata. Hal ini diduga karena pupuk kandang yang digunakan belum cukup matang sehingga belum memberikan dampak yang positif terhadap pertumbuhan dan hasil tanaman. Pupuk kandang yang mempunyai nisbah $\mathrm{C} / \mathrm{N}$ yang tergolong tinggi dapat menyebabkan pupuk kandang menjadi lama terdekomposisi di dalam tanah. Kenyataan ini mengakibatkan unsur hara yang terkandung di dalam pupuk kandang ayam lambat tersedia bagi tanaman. Penggunaan pupuk kandang ayam pada dosis 15 ton/ha dengan nisbah $\mathrm{C} / \mathrm{N}$ yang rendah mampu meningkatkan jumlah daun tanaman kacang panjang (Andi et al., 2012) dan tanaman kolesom (Susanti, 2006). Rendahnya bahan organik tanah akan menyebabkan berkurangnya senyawa-senyawa organik yang berfungsi mengkhelasi ion-ion logam khususnya Al dan Mn (Bertham, 2005).

\section{KESIMPULAN}

Terdapat interaksi antara pupuk hayati mikoriza $5 \mathrm{~g} /$ tanaman dengan pupuk kandang ayam 5 ton/ha yang memberikan hasil terbaik pada variabel bobot polong/petak yaitu sebesar $1,55 \mathrm{~kg} / \mathrm{m}^{2}$ dan bobot polong sebesar 15,46 ton/ha. Pemberian pupuk hayati mikoriza dosis $5 \mathrm{~g} /$ tanaman menghasilkan pertumbuhan vegetatif dan generative yang lebih baik dibandingkan dengan dosis mikoriza lainnya. Dosis pupuk kandang hingga 15 ton/ha belum mampu meningkatkan secara nyata pertumbuhan dan hasil kacang panjang.

\section{DAFTAR PUSTAKA}

Andi, A., Suaib \& Karimuna, L. (2012). Pemanfaatan residu bahan organik dan fosfor untuk budidaya tanaman kacang panjang (Vigna sinensis L.). Berkala Penelitian Agronomi, 1(1), 8-15.

Badan Pusat Statistik. 2018. Produksi Tanaman Hortikultura Nasional. http://www.bps.go.id. 15 Januari 2019

Balai Pengkajian Teknologi Pertanian Bengkulu (BPTP Bengkulu). 2014. Pemanfaatan Lahan Kering Masam dengan Tumpangsari Jagung dan Kacang Tanah di Provinsi Bengkulu. Balai Pengkajian TeknologiPertanian Bengkulu,Bengkulu

Bertham, Y.H. (2005). Respon Tanaman Kedelai [Glycine $\max (\mathrm{L}$.) Merill] terhadap pemupukan posfor dan kompos jerami pada tanah ultisol. Jurnal Penelitian Universitas Bengkulu, 4(2), 78-83.

Bertham, Y.H. \& Nusantara, A. D. (2011). Mekanisme adaptasi genotipe baru kedelai dalam mendapatkan hara fosfor dari tanah mineral masam. J. Agronomi Indonesia. 39(1), 24-30.

Cahyono. (2003). Kacang Panjang. Teknik budidaya dan Analisis Usaha Tani. Yayasan Pustaka Nusantara, Yogyakarta.

Gunadi, N. \& Subhan. (2007). Respons tanaman tomat terhadap penggunaan jamur mikoriza di lahan marjinal. Jurnal Hortikultura, 17(2), 138-149. 
DOI: http://dx.doi.org/10.21082/jhort. v17n2. 2007.p\%25p.

Hartanti, I. (2013). Pengaruh Pemberian Pupuk Hayati Mikoriza dan Rock Phosphate Terhadap Pertumbuhan dan Produksi Tanaman Jagung Manis (Zea mays saccharata Sturt). Skripsi. Fakultas Pertanian, Universitas Riau. Pekanbaru, Riau.

Hendri, M., Napitupulu, M. \& Sujalu, A.P. (2015). Pengaruh pupuk kandang sapi dan pupuk NPK Mutiara terhadap pertumbuhan dan hasil tanaman terung ungu (Solanum melongena L.). Jurnal Agrivor, 14(2), 213-220. DOI: https://doi.org/ 10.31293/af. v14i2.1429.

Lakitan, B. (2004). Dasar-Dasar Fisiologi Tumbuhan. PT. Raja Grafindo Persada, Jakarta.

Lizawati, L., Kartika, E., Alia, Y \& Handayani, R. (2014). Pengaruh pemberian kombinasi isolat fungi mikoriza arbuskula terhadap pertumbuhan vegetatif tanaman jarak pagar (Jatropha curcas L.) yang ditanam pada tanah bekas tambang batubara. J. Biospecies, 7(1), 14-21.

Manuhuttu. A.P., Rehatta, H. \& Kailola, J.J.G. (2014). Pengaruh konsentrasi pupuk hayati bioboost terhadap peningkatan produksi tanaman selada (Lactuca sativa L). Jurnal. Agrologia, 3(1), 68-74. DOI: http://dx.doi.org/10.30598/ a.v3i1.256.

Musfal. (2010). Potensi cendawan mikoriza arbuskula untuk meningkatkan hasil tanaman jagung. Jurnal Penelitian dan Pengembangan Pertanian, 29 (4),154-158.DOI: http://dx.doi.org/ 10.21082/ jp3.v29n4.2010.p154-158.

Nurmala, P. (2014). Penjarangan cendawan mikoriza arbuskula indigeous dari lahan penanaman jagung dan kacang kedelai pada gambut Kalimantan Barat. Jurnal Agro, 1(1), 50-60.

Permatasari, A.D. \& Nurhidayati, T. (2014). Pengaruh inokulan bakteri penambat nitrogen, bakteri pelarut fosfat dan mikoriza asal Desa Condro, Lumajang, Jawa Timur terhadap pertumbuhan tanaman cabai rawit. Jurnal Sains dan Seni, 3(2), 44-48. DOI:10.12962/ j23373520.v3i2.6868.

Rahayu. (2007). Analisis efisiensi serapan N, pertumbuhan, dan hasil beberapa kultivar kedelai baru dengan cekaman kekeringan dan pemberian pupuk hayati. Agrosains 6(2), 70-74.

Sastrahidayat, I. R. (2011). Rekayasa Pupuk Hayati Mikoriza dalam Meningkatkan Produksi Pertanian. Universitas Brawijaya Press., Malang.
Sentana. S. 2010. Pupuk Organik, Peluang dan Kendalanya. Pengembangan Teknologi Kimia untuk Pengolahan Sumber Daya Alam Indonesia. Yogyakarta.

Setiawan, A.B., Purwati, S. \& Toekidjo. (2012). Pertumbuhan dan hasil benih lima varietas cabai merah (campsicum annuum L.) di dataran menengah. Vegetalika, 1(3), 1-11.

Subowo, G. (2012). Pemberdayaan sumberdaya hayati tanah untuk rehabilitasi tanah Ultisol terdegradasi. Jurnal Sumberdaya Lahan,6(2),79-88.

Suparta. I.N., Gede Wijaya, Y. \& Gede, M. (2012). Aplikasi jenis pupuk organik pada tanaman padi sistem pertanian organik. E-Jurnal Agroekoteknologi Tropika, 1(2), 98-106.

Susanti, H., 2006. Produksi Biomassa dan Bahan Bioaktif Kolesom (Talinum triangulare) Pada Berbagai Asal Bibit, Dosis Pupuk Kandang Ayam, dan Komposisi Media Tanam. Tesis. Institut Pertanian Bogor. Bogor.

Sutedjo. M.M. (2002). Pupuk dan Cara Pemupukan. Rineka Cipta, Jakarta.

Suryati, D. \& Anom, E. (2014). Uji Beberapa konsentrasi pupuk cair Azolla (Azolla pinnata) pada pertumbuhan bibit kelapa sawit (Elaeis guineensis Jacq.) di pembibitan utama. Jurnal Online Mahasiswa (JOM) Bidang Pertanian, 1(2), 1-13.

Tambunan, Ardian. S., Fauzi \& Guchi, H. (2014). Efisiensi pemupukan $\mathrm{P}$ terhadap pertumbuhan dan produksi tanaman jagung (Zea mays L.) pada tanah andosol dan ultisol. Jurnal Online Agroekoteknologi, 2(2), 414-426.

Widiastuti, H., Guhardja, E., Sukarno, N., Darusman, L.K., Goendi, D.H. \& Smith, S. (2003). Arsitektur akar bibit kelapa sawit yang dinokulasi beberapa cendawan mikoriza arbuskula. Menara Perkebunan, 7(1), 28-43.

Winarso, S. (2005). Kesuburan Tanah. Gava Media, Yogyakarta

Zainal, M., A. Nugroho, A. \& Sumiarti, N.E. (2014). Respon pertumbuhan dan hasil tanaman kedelai (Glycine max (1.) Merill) pada berbagai tingkat pemupukan $\mathrm{N}$ dan pupuk kandang ayam. Jurnal Produksi Tanaman, 6(2), 484-490. 